\title{
Cathodoluminescence and trace elements features of hydrothermal $K$-feldspar and quartz in the Liubagou gold-molybdenum deposit, Inner Mongolia, China
}

\author{
Y.M. ZHANG ${ }^{1}$, X.X. GU ${ }^{1}$, BRIAN RUSK ${ }^{2}$ \\ ${ }^{1}$ State Key Laboratory of Geological Processes and Mineral \\ Resources, China University of Geosciences, Beijing \\ 100083, China (zhangyongmei@cugb.edu.cn) \\ ${ }^{2}$ Department of Geology, Western Washington University, \\ Bellingham, Washington 98225, USA
}

The Liubagou Au-Mo deposit is hosted by Archean metamorphic rocks, and orebodies occur as subparallel, sheetlike ore vein that are confined to the nearly EW-trending faults. Wall rock alterations mainly include potassic, phyllic, and propylitic alteration. Ore-forming process can be divided into four stages: K-feldspar-quartz-molybdenite stage (I), quartz-pyrite-epidote/chlorite stage (II), quartz-polymetallic sulfide-gold stage (III), and carbonate-sulfate-quartz stage (IV). The studies of SEM-CL and LA-ICP-MS of K-feldspar and quartz of different hydrothermal stages indicate that the $\mathrm{CL}$ textures and trace element concentrations of K-feldspar and quartz are effective indicators tracing the mineralization. $\mathrm{K}$-feldspar and quartz in stage I are characterized by high CL intensity, high Ti concentrations (tens of ppm up to 100ppm), high $\mathrm{Ba}$ (ranging from several thousand up to thousands ppm) and $\mathrm{Sr}$ concentrations (several hundred $\mathrm{ppm}$ ), which show characteristics of high-temperature hydrothermal fluid. Quartz in ore-forming stage (stage II and III) are characterized by low CL intensity, no CL textures and low Ti contents (generally $<1 \mathrm{ppm}$ ). Overprinted by late hydrothermal superimposition, altered $\mathrm{K}$-feldspar in late stage has low CL intensity, low Ti concentrations (generally $<1$ ppm to several ppm). The contents of $\mathrm{Ba}$ and $\mathrm{Sr}$ decline one order of magnitude compared with those in stage I. Barium and $\mathrm{Sr}$ came from early K-feldspar provide important material source for the precipitation of barite and celestite. Overall, Mo mineralization occurred predominantly in stage I, characterized by K-feldspar and quartz of high Ti contents and high CL intensity. Gold is precipitated mainly during stage III with quartz of low $\mathrm{Ti}$ and $\mathrm{CL}$ intensity, less commonly, is hosted in the altered K-feldspar of low $\mathrm{Ti}$ concentrations and low CL intensity during stage II and/or III. The research was funded by the National Natural Science Foundation of China under grants of 41302064 and 41572062 . 